\title{
Happy? A critical analysis of salvation in Ellen Charry that portrays human flourishing as healing, beauty and pleasure
}

\author{
Author: \\ Nadia Marais ${ }^{1}$ \\ Affiliation: \\ ${ }^{1}$ Department Systematic \\ Theology and Ecclesiology, \\ Stellenbosch University, \\ South Africa \\ Correspondence to: \\ Nadia Marais \\ Email: \\ nadiam@sun.ac.za
}

Postal address:

PO Box X967, Somerset West

7129 , South Africa

\section{Dates:}

Received: 27 May 2014

Accepted: 29 Oct. 2014

Published: 25 Mar. 2015

How to cite this article:

Marais, N., 2015, 'Happy?

A critical analysis of salvation

in Ellen Charry that portrays

human flourishing as healing,

beauty and pleasure', Verbum

et Ecclesia 36(1), Art. \#1359,

10 pages. http://dx.doi.

org/10.4102/ve.v36i1.1359

\section{Note:}

This article is part of the doctoral research for a $\mathrm{PhD}$ in Systematic Theology at Stellenbosch University, with the title 'Imagining Human Flourishing? A critical analysis of contemporary soteriological discourses'.

\section{Copyright:}

C 2015. The Authors

Licensee: AOSIS

OpenJournals. This work is

licensed under the Creative

Commons Attribution

License.

\section{Read online:}

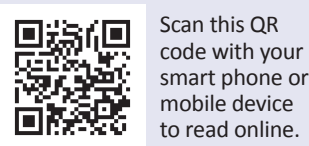

Happiness and human flourishing has increasingly, especially in American and German theological writing, become a focus in systematic theological research on creation, salvation and eschatology. The doctrine of salvation has particularly interesting (including etymological) connections with the notions of well-being and health. This paper proposes to do a critical analysis of well known American happiness theologian Ellen Charry's portrayal of salvation, who engages with classical theology, Christian doctrine and positive psychology to reposition the notions of 'happiness' and 'human flourishing' within theological reflection. The art of happiness has, for Charry, to do with knowing, loving and enjoying God. In this article it will be argued that Charry's portrayal of salvation as being 'happy' shapes an understanding of flourishing that entails healing, beauty and pleasure.

\section{Introduction}

Ellen Charry, Margaret W. Harmon Professor of Systematic Theology at Princeton Theological Seminary, has written extensively on Christian doctrine, ${ }^{1}$ issues regarding moral formation ${ }^{2}$ and the intersections between theology and psychology. ${ }^{3}$ Recently her research has increasingly focused on the latter, to the extent that she is in the process of writing a book on 'positive theology' and has recently been invited to present lectures at the Centre for Positive Psychology of the University of Pennsylvania in Philadelphia. ${ }^{4}$

Ellen Charry is best known for her work on classical theology and a theological engagement with the topic of happiness. 'Theology', writes Ellen Charry (2004b:19), 'is concerned with human happiness.' For her, 'to discount the importance of human flourishing is to misunderstand theology and its purpose', since theology is (1) about life in this world and (2) about the enjoyment of this life in this world (Charry 2004b:19). Happiness may have to be redefined theologically, but it ought not be abandoned because it has come to be associated with hedonism or emotional euphoria, argues Charry (2007:31). Indeed, 'it is far more rewarding to think of happiness in theological terms than in emotional terms' (Charry 2004b:20).

She argues that the task of theology is 'to help us know, love and enjoy God better' (Charry 2004b:19). Dwelling in God implies both enjoyment and glorification, whereby individuals are

1.Cf. 'The moral function of doctrine' (Charry 1992), 'Academic theology in pastoral perspective' (Charry 1993), By the renewing of your minds (Charry 1997), and 'To know, love, and enjoy God' (Charry 2002).

2.Cf. 'How should we live?' (Charry 2003a), 'On Happiness' (Charry 2004b), 'Christian witness to contemporary culture regarding sex' (2004a), and 'The crisis of modernity and the Christian self' (Charry 1998).

\section{Cf. 'Positive theology' (Charry 2011).}

4.This follows from her remarks in an interview that I had with her on 03 April 2013 in Princeton, New Jersey. Professor Charry mentioned in this interview that she is the first theologian to be invited to lecture and present her research at this renowned Centre, where the so-called 'father' of positive psychology, Martin Seligman, resides and works. In the mentioned forthcoming book, wherein she wants to engage more fully with positive psychology than she has in previous publications, the interdisciplinary implications of her theological research in the matter of human flourishing and happiness will hopefully become even clearer. Yet Eric Johnson describes Charry's book on God and the art of happiness (2010) as already 'an example of a Christian positive psychology' (2011:256). Charry's approach, he adds, is unusual and 'radically different' from contemporary (positive psychology) research on happiness in that it is not based on naturalism and that it does not equate positive feelings with pleasure, but 'offers a decidedly theistic understanding of happiness and human flourishing' that parts ways with the known and accepted empirical approach that positive psychologist have been employing for the last two decades (Johnson 2011:256; original italics). Charry's approach, argues Johnson (2011:256), is helpful in that it extends the 'far too basic, inchoate, and individualistic' understanding of happiness as 'pleasure' or 'fulfillment' to 'one's relationship with God.' If this is taken to be a first interdisciplinary implication of Charry's theological work on happiness and human flourishing then a second interdisciplinary implication could surely be described as her 'skillful weaving of self-love into a human flourishing, then a second interdisciplinary implication could surely be described as her 'skilful weaving of self-love into a theocentric account of hor a and (2) including the (Johnson 2011:256) but instead relies on her ow biblical interese (including Boethius, Aquinas and Butler) 'the pivotal theologian for Charry is Augustine' (2012:362). There may be many more intra- and interdisciplinary implications and restrictions to Charry's 'own paleoorthodox path' which cannot and will not be traced and explored in this article, but the point still stands: Charry's (recent) past and (forthcoming) future research on happiness and human flourishing is charting a theological way into a research focus long dominated by positive psychologists (cf. Johnson 2011:256). 
blessed and the well-being of society is enhanced (Charry 2004b:19). Theology is concerned with human happiness because God is concerned with the happiness of human beings. ${ }^{5}$ Indeed (Charry 2002), argues that:

God, not the church or modern scholarship, is the center of happiness. The means to happiness is the truth of God that is to goodness, beauty and wisdom. This is to say that God is the psychological and moral foundation, not only of personal fulfillment, but also of just societies. (p. 176)

Yet theology has often misunderstood and misconstructed its own purpose and task, argues Charry. She writes (1997) that she is persuaded that:

$[O]$ ver the course of centuries of action and reaction to the ups and downs of theological practice, theology has lost its ability to address questions of happiness and perhaps even goodness. (pp. 17-18) ${ }^{6}$

It is for this reason that she turns to the classic theologians 'who based their understanding of human excellence on knowing and loving God, the imitation of or assimilation to whom brings proper human dignity and flourishing' and who 'held that knowing and loving God is the mechanism of choice for forming excellent character and promoting genuine happiness' (1997:18) - to (re)formulate the nature and function of Christian doctrine. Happiness has a 'soteriological calling', writes Charry (2010:xii), and therefore any understanding of happiness from her work will need to account for her understanding of salvation. Charry's understanding of salvation is embedded in her interpretation of the formative nature and function of Christian doctrine - which is, in turn, shaped by the methological strategies that she employs to interpret Christian doctrine.

\section{Nature and function of Christian doctrine}

For Ellen Charry, Christian doctrine means 'teaching and instruction' (doctrina in Latin and dogma in Greek [Charry 2006b:152]). In her own work, however, Charry distinguishes between doctrine and dogmatics. 'Doctrine,' writes Charry (2006b:152), 'came to denote a belief, theoretical opinion, dogma, tenet, or system of tenets in the late seventeenth

\footnotetext{
5. As to the reasoning behind Ellen Charry's argument for the 'retrieval' of a Christian doctrine of happiness now she writes (2010:xii): 'With affection for Christian doctrine of happine pieties and theologies and a towering, fear of hell are out of favor; Christianity is in an upbeat mood, and Christians reassure one another that God loves and encourages them in their struggles. Whilst this book is written to address older weaknesses in Christian theology, it addresses them in order to reclaim Christianity's offering of happiness from secular captivity.' Charry therefore addresses two challenges with this particular book, namely (1) an overemphasis on sin and hell in (Protestant) theology; and (2) secular definitions of happiness (2010:xii). Arguably, however, '[ $r$ ]elatively little attention is ... paid to the hindrances of sin on happiness' or 'the role of Christ's death (and atonement) and resurrection in Christian happiness' (Johnson 2011:257). Some account of the functioning of sin within a doctrine of happiness and an account of salvation that takes sin seriously is perhaps not adequately accounted for within Charry's theologica 's theological tiness and human flourishing, as some (like Eric Johnson, would suggest.
}

6.She refers to the work of Alasdair MacIntyre (who 'has pointed this out for moral philosophy') and Charles Taylor (who 'has chronicled the career of this loss since the Enlightenment') in this regard, and argues that these 'narratives can be paralleled within theology' (Charry 1997:17). and early eighteenth centuries. ${ }^{7}$ Dogmatics, she would argue (2005b), is:

[T] he elaboration of Christian doctrine as set forth in the three articles of the Nicene Creed, each article of which identifies one of the three ways in which God is known. (p. 203)

Yet it is with the nature and function of Christian doctrine, more than dogmatics or systematic theology, that Charry would be concerned. In her book By the renewing of your minds (1997), Charry argues that 'classical doctrinal theology is pastorally motivated and that its end is human flourishing' (2010:ix). In this book, and in its sequel entitled God and the art of happiness (2010), three convictions shape her arguments regarding the nature and function of Christian doctrine, namely (1) that ' $[d]$ octrine is pastoral', (2) that 'theology and spirituality belong together' and (3) that 'the purpose of what seems to be practically irrelevant formulas such as God is One and Three is to promote love of God and nourish a godly life' (1997:xiii).

These convictions culminate, writes George Lindbeck (in Charry 1997:xiii), in the argument that doctrines have 'lovepromoting' and 'life-nurturing' force. In Ellen Charry's thinking, Christian doctrine has an overwhelmingly formative task (1997:18). Christian doctrine guides and shapes believers into those who know, love and enjoy God. This twofold function of doctrine, of guiding and shaping the lives and identities of believers in particular ways, culminates in what Ellen Charry describes as 'the pastoral function of Christian doctrine', as the subtitle of one of her books attests to (cf. 1997).

Firstly, Christian doctrine guides or directs the life of the believer; alternatively stated, Christian doctrine has to do with knowledge. The foundation of knowledge and direction, more specifically, is 'knowing and loving God' in that 'life's goal is conformation to God' (Charry 1997:4). Yet 'development of character will not happen without knowledge' (1997:19). Indeed (1997):

Unless we center in God, Christians claim, we are lost. We do not really know who we are, from whence our life takes its orientation, or where we ought to direct our energies. Without God we are liable to float aimlessly at the mercy of volatile emotions and hormones or be seduced by less worthy companions than the maker of heaven and earth. Or we may turn to ourselves in a misguided search for fame, wealth or power. (p. 3)

Ellen Charry argues that 'one of the tasks of primary religious doctrines is to guide believers' (1997:17). Yet Christian doctrine has to do with teaching and learning, and ultimately with knowledge and the conditions for knowing, and therefore Charry takes issue with what she regards as the predominant view of knowledge today. Purely objective, rational knowledge not only entails an outdated and overly idealistic epistemology (cf. Charry 1993:102; footnote 16), but is also undesirable within theology. Virtue is an important aspect of what she calls 'good knowledge' (Charry 2006b:157),

7.She adds that "dogmatic" is a seventeenth century Protestant term" (2006b:152). 
for it expresses the need for God's grace in forming and transforming human beings. Knowledge is formative, in that there is an intimacy between the knower and that which is known (Charry 2006b:166). Indeed, 'the participation of knower and known in each other is the blessing of being known, knowing, and learning' (2006b:166). ${ }^{8}$ Knowledge is, furthermore, a source of blessing because ' $[i] \mathrm{t}$ requires being with, staying with, examining, and attending to something so that it yields to us as much of itself as possible' (2006b:166). This also pertains to the relationship between God and human beings. Charry writes that 'God is blessed by our knowing him; we are blessed by knowing him' (2006b:166). Contemplation is an active, engaged, practical knowledge that values wisdom and goodness; Charry likens the contemplation of divine things to 'absorbing the aroma of God' (2006b:166). Wisdom, moreover, is a particular form of knowledge (2006b):

$[I] \mathrm{t}$ is what remains in the soul after observation is complete. It is what stays with us after the impression that the encounter with the text or the lesson leaves behind - sometimes consciously and sometimes not. These insights nourish and expand us for good or ill ... [G]ood knowing is to be taught by what one seeks to know. This is a moral and communal art that requires welldeveloped instincts and tendencies. When done well, it shapes the soul for a wise, good, and productive life. Good knowing is sapiential; it is only possible by divine grace. (p.167)

Knowledge of Christian doctrine does not, therefore, only guide or direct the life of the believer, but also shapes and reshapes, forms and reforms both the knower and the known.

Christian doctrine, secondly, forms or shapes the life of the believer; alternatively stated, Christian doctrine has to do with wisdom. ${ }^{9}$ Good knowledge is a form of contemplation that is directed towards wisdom. For Charry, the act of knowing is a skill or craft or art 'by means of which the soul grows by God's grace' (Charry 2006b:167). Good knowing is sapiential knowing, argues Charry (2006b:167) - on the one hand it is 'a moral and communal art that requires welldeveloped instincts and tendencies'; on the other hand 'it is only possible by divine grace.' Knowledge can enhance or damage one's own soul or the souls of others; however, sapiental knowing 'shapes the soul for a wise, good, and productive life' (Charry 2006b:167). Therefore the wisdom of God, or sapience, is the foundation of a life of dignity, a life lived well, a good life, a happy life. For her, there is an integral link between the knower and the known, in that the knower is emotionally connected to what is known, and that which is known is shaped by the knower. This she names 'wisdom' or 'sapience'. In both the Western and Eastern theological traditions, argues Charry (1997:4), God is regarded as 'the origin and destiny of human happiness.'

8. Here Charry calls upon post-critical philosophy (and figures such as Michael Polanyi, Gabriel Marcel, Hans Georg Gadamer, Alasdair MacIntyre and Charles Taylor) to support her point that 'the knower shapes the known' and that 'the known also shapes the knower' (Charry 2004c:32).

9.Ellen Charry defines sapientia (Latin for 'wisdom') as 'the response of loving God' and 'the capacity to share in God' (1993:94).
Although Ellen Charry does not and would not describe herself as a feminist theologian, ${ }^{10}$ here she is, as she herself admits (1997:18), indebted to the feminist insights that (1) 'some theological traditions have at times been so driven by cognitive concerns as to deny the role of affect and experience in religious knowledge' and (2) resistance to the view that suffering is redemptive in its own right (a view which, she adds, 'is not supported by the biblical materials or the tradition's strongest theologians' [1997:18]). ${ }^{11}$ These insights form an 'important impetus' in her work (1997:18). In her article 'Welcoming Medieval Christian women theologians' (2003b) Charry makes the case for two additional insights (which she garners not, in this case, from feminist theologians, but from medieval women theologians), namely (3) that imagination is one of the greatest contributors to Christian theology (2003b:2); and (4) that the exegesis of doctrine is not separate from the spiritual life, but that it serves to bring people into 'the divine presence' (2003b:3). These insights accentuate Ellen Charry's argument that 'the doctrinal tradition is not an end in itself, but a means to help us grow, love and enjoy God better' (2003b:4). For Charry, as for the medieval women theologians whom she has studied, theology 'is a path toward a truly satisfying life' (2003b:4).

Christian doctrine is formative, in that it guides or directs (through knowledge) and shapes or forms (through wisdom) the lives of believers. Such a description of Christian doctrine arguably provides a helpful context as to how salvation functions in Charry's thinking and writing. A second important insight into Charry's understanding of salvation pertains to the methodological strategies she employs when interpreting doctrine.

\section{Methodological strategies in interpreting Christian doctrine}

Ellen Charry employs a collection of methodological strategies in her interpretation of Christian doctrine as formative (guiding and shaping), namely (1) pastoral, (2) apologetic and (3) aretegenic strategies.

Formation firstly entails a pastoral perspective or interpretation of faith and the life of believers. It is particularly in her two books, By the renewing of your minds (1997) and God and the art of happiness (2010), that Charry works out her main argument regarding Christian doctrine, namely that 'classical doctrinal theology is pastorally motivated and that its end is human flourishing' (2010:ix). Here she argues that Christian theology and Christian doctrine in particular have always, throughout the ages, been deeply pastoral and concerned with the healing of human beings. Pastoral interpretation is therefore a first

10.This follows from her remarks in an interview that I had with her (Marais 2013).

11.Although not herself a feminist theologian, Charry's insights and work on human flourishing is appreciated by feminist theologians such as Leanne Van Dyk, who describes Charry's book (1997) as 'deeply learned', 'well written', 'carefully researched' - in short, as 'a prophetic call to professional teachers of theology to researched' - in short, as 'a prophetic call to professional teachers of theology to
renew the tradition of teaching doctrine for the formation of virtue and for the knowledge of God' (Van Dyk 1999:104). 
methodological strategy that Charry employs in her work, which takes her first point regarding Christian doctrine that 'knowing God' facilitates healing - seriously.

Wise, virtuous knowing entails both the need for the gift of God's grace and the honing or development of certain skills. If 'knowing God is an art of the especially blessed soul' (Charry 2006b:169), then the skill of knowing God becomes a central part to the identity of believers (Charry 2006b:169). In By the renewing of your minds (1997) Charry makes use of the striking analogy of medicine to express how she means to interpret Christian doctrine, even as she points out that this analogy is not 'paramount' to her arguments in this book. Indeed, writes Charry (1997:11), 'the theme of Christianity as therapy runs throughout Christian theology' and 'theology as spiritual medicine can be traced back to Plato'. The therapeutic model for knowledge of God would be maintained in the patristic age (Augustine) up to the Reformation (Calvin), argues Charry (1997:11).

Christian doctrine's analogy to medicine expresses this first methodological strategy. Charry charts five ways in which theology is analogous to medicine. Firstly, medicine and theology both require information, in the specific knowledge of physical (medicine) and psychological (theology) processes within human beings that need to be understood in order to effect physical (medicine) and spiritual (theology) healing (Charry 1997:12). Secondly, medicine and theology both demand 'highly skilled judgment' (or 'the ability to interpret clinical data based on the knowledge at hand' [Charry 1997:12]). Theology, like medicine, 'relies on careful assessment of available knowledge' that includes theological practice as well as theoretical constructs or theological language (Charry 1997:12-13). Thirdly, medicine and theology both imply 'the need for trust and obedience' if these are to be 'successfully practiced' (Charry 1997:14). Fourthly, medicine and theology both contain elements of risk and uncertainty, in that healing cannot be guaranteed (Charry 1997:14). Fifthly, in both medicine and theology there may be malpractice, and therefore ' $[k]$ nowledge in theology and medicine is revisable within limits set by their respective traditions' (Charry 1997:14). In short, if 'Christianity is medicine for the soul' (Charry 1997:11), then theology - and salvation - has to do with healing: specific knowledge, sound judgment, adherence, risk and learning. Indeed, '[s]alvation is the healing of love that one may rest in God' (2010:xi).

In Charry's first methodological strategy, namely a pastoral interpretation of Christian doctrine, salvation as healing deals with knowing God. In her arguments regarding theological training (Charry 2002) and the ordination of homosexual persons (Charry 2004a) it becomes particularly clear that, for her, theology is inherently and unmistakably pastoral in its concern for the flourishing of human beings. Here too salvation is portrayed as healing and (spiritual, psychological) health. Within her treatment of happiness in God and the art of happiness (2010), she writes that this book is an offering that carries 'a special burden for those traumatized by life's adversities - that they may be comforted and encouraged' (2010:xii). This first methodological strategy is formative in that it shapes and guides Christian believers toward knowing God as a way towards healing.

Formation secondly, deals apologetically with core affirmations of the Christian faith. There is a collection of widespread, interesting passages in Ellen Charry's writing, where she deals with a range of apologetic concerns, including proof for the existence of God (cf. 2006b:168-169), the importance of the turn from the modern self to the Christian self (cf. 1998) and the centrality of happiness in the Christian tradition (cf. 2007). However, it is with regard to what Ellen Charry calls 'primary theology' or 'primary Christian doctrines and teachings' (1997:5) that the full scope of Charry's apologetic concerns are revealed. Ellen Charry's second methodological strategy in interpreting Christian doctrine is closely linked to her views on what she regards as the two branches of theology. She distinguishes between two kinds of theology, namely primary (or sapiental) theology and secondary (or scholastic) theology. ${ }^{12}$

Primary theology has to do with asking questions as to who we should become and how we should live (Charry 2006b:144), in that it 'seeks the knowledge of God so that we come to dwell in the truth; for the truth will make us happy and good, and in that way, free' (Charry 2006b:145). It is clear, from the outset that she favours this understanding of theology, and she calls on all her considerable (classic) resources - most notably Augustine and Thomas Aquinas to support her in her argument for a return to 'normal', 'sapiental', 'primary' theology (cf. 2006b, 1997). The primary goal of theology, she would argue (2006b:152), is 'to incite persons to good and happy lives.' Primary theology is 'normal theology', or theology that is 'directed toward wisdom and goodness' (Charry 2006b:152) and which seeks to shape human beings for life with and in the truine God (2006b:161).

Secondary theology is 'professional academic theology', which finds its intellectual home at universities and which is tasked with gathering, coordinating and organising 'the wealth of scriptural, theological, and philosophical material' available to theological reflection (2006b:155). This 'branch' or 'way of doing' theology has been shaped by what Charry describes as three epistemological crises: (1) the pressure on theology to become an academic discipline (which Charry describes as scholasticism, or 'the West's recovery of Aristotle in the twelfth and thirteenth centuries' [2006b:145]); (2) the pressure to maintain intellectual credibility (whereby Charry points to modernism and the 'experimental science' and 'empiricism' of the 17th century [2006a:146]); and (3) the pressure to remain intellectually coherent and meaningful (which Charry sees as a response to postmodernism and the rejection of truth, knowledge and goodness today

12. Ellen Charry describes the epoch of primary theology from the late second century to the 17th century, and the age of secondary theology from the 12th century and throughout the 17th century ('with a hiatus during the early years of the Protestant Reformation in the sixteenth century,' she adds [2006b:149]). 
[2006b:146]). The combined pressure of scholasticism, modernism and postmodernism has increasingly shaped theological reflection into an academic discipline (with its respective 'fragmented subdisciplines') (2006b:150), which aims to be intellectually credible, coherent and meaningful. ${ }^{13}$

The distinguishing question for her in this regard, then: 'Is theology a technique for promoting orthodoxy against challenge, or is the formation of the soul for the enjoyment of God?' (2006b:156).

Primary theology or primary doctrines are 'first-order assertions' which describe 'the practically oriented content of the faith', whereas secondary theology or secondary doctrines are 'second-order thought' which deal with theological method (1997:5). Throughout her work, but particularly in her book By the renewing of your minds (1997), Charry argues convincingly for a (re)turn to primary theology or primary doctrines. Her concern that a central task of theology should be 'to assist people to come to God' (1997:5) makes the apologetic slant of her understanding of primary theology or doctrines clear. She adds that such a description of theology's task is not unproblematic, in that it is 'a contested idea for modern theology, which has moved away from primary Christian beliefs and focused on theological method instead' (1997:5).

Moreover, secondary theology or doctrines are important, in that they maintain the identity and coherence of Christian faith communities. Yet as she points out, 'issues of method do not exhaust the theological task' (1997:5). Secondary theology and primary theology entail different theological tasks; yet Charry argues that secondary theology 'should support the primary doctrines of a community' (1997:6). She calls upon classical theology - Augustine and Thomas Aquinas in particular - to argue for the importance of 'sapiental theology', a mode of primary theology that is concerned with 'helping people flourish through knowing and loving God' (1997:6).

Primary doctrines are therefore concerned with both knowledge and practice. Ellen Charry regards the choice between insight-oriented and practice-oriented theological reflection as a false dichotomy. Instead, she argues for the complexity of human beings in which both knowing and doing feature equally (1997:4). Exactly herein lies the beauty of the vision of happy human beings. Salvation is the beauty of 'loving God' and 'being loved by God' that guides, shapes and transforms human beings. She reminds the reader that

\footnotetext{
13.Another way in which Ellen Charry describes what she calls 'the loss of theological realism' is by way of three pivotal moments: (1) John Locke's rationalism, (2) David Hume's empiricism and (3) Immanuel Kant's critique of the classical proofs for God's existence, and hence, faith (1997:6-11). She suggests that modern understanding of truth and knowledge developed by way of these three stages: 'Locke separated faith from knowledge developed by way of these three stages: "Locke separated faith from knowledge, denying the importance of trust as an element in truth. Hume insisted on the repeatability of events as a sign of their truth and disallowed inferential reasoning, tentativeness, and discerning judgment. Kant pointed out that the conditions for knowing lie within the mind itself and that human knowin cannot transcend the limits of time and space within which the mind operates' (Charry 1997.10). For her own, more extensive argument regarding the various stages or moments that have led to what she calls 'the loss of theological realism' see Charry (1997).
}

' $t]$ he Christian tradition says that God is able to teach us to love by loving us quite beautifully unto salvation' (2007:32). Moreover, there is beauty in the holiness that comes from obeying God (Charry 2010:268). Indeed, as Charry writes (1998:105): 'Turning to God ... emancipates us from our unloveliness.' The interchange between knowledge and practices enables human beings to flourish by God's grace and love. This second methodological strategy is formative in that it shapes and guides Christian believers toward loving God as a skill in which God's beauty and our beauty stand revealed.

Formation thirdly, has an aretegenic focus. Throughout her books and the many articles that she has written on various topics, Charry makes the point that Christian faith plays, and has always played a guiding and shaping role in the lives and identities of believers. Moreover, the aim or focus of Christian doctrine is the good formation of character (or what Charry calls 'salutarity'): 'They seek to form excellent persons with God as the model' (Charry 1997:vii). This third methodological strategy, wherein the pleasure of 'enjoying God' guides and shapes believers into happy people, expresses yet another understanding of salvation - namely, salvation as enjoyment or pleasure. Aretegenic analysis is not only concerned with moral formation, but with the joy, enjoyment and pleasure that the transformation of human beings evokes. ${ }^{14}$

Charry uses the adjective 'aretegenic' (from a combination of the Greek words arete ${ }^{15}$ and gennao, which together mean 'to beget virtue') to indicate and describe 'the virtue-shaping function of the divine pedagogy of theological treatises' (1997:19). By using the term 'aretegenic' Charry attempts to 'represent the moral and psychological dignity and honor which Christianity encourages' (1993:101; footnote 15). Moreover, for her the term refers to 'the nobility of human life' (1993:101).

The moral shaping function of Christian doctrine is understood by way of the 'salutarity principle', which Charry describes as the theological unearthing of the divine pedagogy 'in order to engage the reader or listener in considering that life with the triune God facilitates dignity and excellence' (1997:18-19). Ellen Charry's third methodological strategy therefore considers virtue ethics by way of what she calls the 'salutarity principle'. Yet Charry is not satisfied with a virtue ethics approach alone, and makes a point of taking character formation seriously (1997):

What constitutes excellence from a Christian point of view, however, is harder to pin down. At times Christian excellence has centered on a specific virtue, like love, humility, selfdenial, or self-sacrifice. At other times clusters of virtues,

14.Ellen Charry makes the point explicitly in an article wherein the relationship between sacraments and doctrines are attended to. What we know, argues Charry, is shaped by 'sensuous as well as cognitive experience' (2005b:209). The pleasure of a happiness that is grounded in Christian doctrine involves the attraction to and attractiveness of God - in her words: 'We can only take refuge in that which looks and tastes good. God must seduce us' (2005b:209).

15. Here she also refers to Aristotle, for whom arete would denote 'moral excellence' (Charry 1997:19). 
such as the three theological virtues - faith, hope and love have been highlighted ... This work does not identity a specific Christian norm of human excellence against which subsequent construals of goodness are judged. It focuses not on character traits but on various mechanisms of character formation. (p.19)

In order to do this, Charry makes a methodological choice for what she calls 'a turn to the (theological) tradition for guidance' (1997:17). Charry employs classic theological treatises, and in particular those of Augustine and Thomas Aquinas, to argue for 'the reclamation of the pastoral function of doctrine' (1997:17). She accounts for this approach as follows. Firstly, Christian theology stands within a 'historically recognizable tradition' which requires continuous reinterpretation (1997:17). A turn to the tradition is therefore required, if Christian doctrine is to be faithful to its nature and function. Secondly, secular culture can be of only 'diminished assistance' to theology, in that it 'seems to have spent its moral and intellectual capital' (1997:17). Even though theology may still learn a great deal from 'secular philosophies and ideologies', it may well be that theology also has important contributions to make. Thirdly, a historical consciousness is important not only because it reminds us how limited our 'own historical vantage point' is, but also because 'we moderns need the older author's understandings of human psychology, of how knowing and loving God functions in people's lives' (1997:17). Morever, '[w]e also need their views on pastoral responsibility, as well as their insights into God's strategies for human flourishing' (1997:17). It is a turn to tradition that may enable modern theologians and theologies to check 'the prejudices and limitations of our own time and place' (1997:17). Ellen Charry constructs a pastoral Christian theology by (re)turning to the theological tradition (and in particular to what she calls 'classical theology') and by (re)considering and (re)learning from our theological forebears (1997:17).

Such a turn to the tradition implies more than simply (re) reading and (re)interpreting classical authors such as Augustine and Athanasius. For Ellen Charry, the turn to tradition also implies a particular hermeneutical strategy, which she calls 'aretegenic reading'. Aretegenic reading or analysis attends to the moral shaping force or potential 'the psychological dynamics' and 'rhetorical art' - of a text (1997:20). Aretegenic reading as hermeneutical strategy could accomplish two tasks. Firstly, texts that are read aretegenically 'arouse awareness of a lack' and 'create desire', in that reading becomes 'reading for pleasure' (Charry 1997:22). Secondly, stories shape 'an ability for self-transcendence' and 'the possibility for change' (Charry 1997:22). Not only is aretegenic reading concerned with the moral formation through processes of discernment, but aretegenic reading also generates pleasure in and for the reader (1997:22). A pivotal part of this methdological strategy is therefore the generation of desire and pleasure for the Christian believer. The pleasure that a Christian believer finds here is the pleasure of stories, and in particular 'the stories of God enfolded in the doctrines' which guide and shape patterns of pleasure (Charry 1997:22). ${ }^{16}$

Yet pleasure is both a given and a practice. Salvation, upon this view, has to do with enjoyment and delight - with enabling believers, through Christian doctrine, 'to desire and delight in God so that their dignity, relationships to persons and things, and visions of human excellence and a just social order stem from that delight' (1993:102). Indeed, 'virtue', writes Charry (2007:31), 'gives genuine pleasure'. This third methodological strategy is formative in that it shapes and guides Christian believers toward enjoying God as a source of pleasure and joy (cf. Charry 2007:32).

Ellen Charry's pastoral, apologetic and aretegenic strategies are eloquently expressed in her constructive proposal for what she calls 'asherism', which works out 'the healing process in a life of reverent obedience to divine commands that shape character and bring moral-psychological flourishing and enhance societal well-being' (2010:xi). 'Asherism' is derived from the Hebrew word asher, which means 'blessed' or 'happy' (2010:xi). Charry defines 'asherism' as the 'enjoyment of life through dynamic obedience to edifying divine commands that enable us to flourish that God may enjoy us and we enjoy God' (2010:ix). In asherism, the close relationship between happiness and salvation stands revealed. 'Asherist soteriology', writes Charry (2010:xii), is to be understood christologically, in that 'happiness is being healed by Jesus with and for the wisdom of love'. Asherism is a form of practicing the happy life, in two directions: (1) by being healed by Christ and thereby being enabled to heal others; and (2) by being therapeutic when being part of the healing process of others. In short, ' $[b]$ eing healed enables healing, and healing heals' (Charry 2010:268).

In her pastoral interpretation of Christian doctrine, knowing God facilitates the healing work of salvation. In her apologetic understanding of Christian doctrine, loving God is a source of beauty and beautification. And in her aretegenic view of Christian doctrine, enjoying God is a skill of good and happy people. These three methodological strategies shape her understanding of salvation as living and being well, where healing, beauty and pleasure are guiding and shaping forces in the lives of human beings.

\section{Salvation as living and being well}

The Christian story's aim is the salvation of humankind (Charry 1993:103). Indeed Charry (2004c) suggests that:

\footnotetext{
16. Ellen Charry understands that 'stories' are not synonymous with 'fiction', however 'Stories' are a fundamental part of Christian faith, where fiction has stood in for religion in many ways (1997:24): '[F]iction can claim to bind the reader together with others; but although the reader may be lifted momentarily into the company of great and exemplary characters, unless the reader makes a serious commitment of great and exemplary characters, unless the reader makes a serious commitment to them or lives in a community that reinforces the values and behaviours they lift up, the new friends vanish the moment the book is closed. The social contex provided by reading, designed to lift the reader out of isolation, is of limited scope The company we keep must carry over into life. Unless we induce our real-life riends to read this novel, or see this film, and then discuss it with them, or becom college teachers so that we can talk about our favourite books with our students, we are still on our own in interpreting and making the final judgment on whethe the world offered by the author merits our redesigning ourselves.'
} 
No one doubts that Christianty offers salvation. The longing to be well/whole/elected/repaired/liberated/transformed/ released/redeemed/shriven/forgiven/restored/justified/ sanctified/glorified/blessed is based on the observation that all is not well - with us, that is. We want it to be, but cannot make it so, perhaps cannot even imagine what being 'well' would look like. (p. 291)

For Ellen Charry, salvation has to do with imagining the psychological and moral wholeness and well-being of individuals and communities (1993:103). She works with two expressions of the vision of salvation, of living and being well.

Firstly, salvation is described as healing, which she calls 'a psychological vision of salvation' (2004c:292). Here salvation is God's mercy in the face of our sinfulness, which soothes, comforts, calms, relieves the psychological anxieties and hurt surrounding failure and the fear of divine punishment. Another version of this vision of salvation is hope in the (bodily) resurrection, which becomes the antidote to the fear of death (2004c:293). This is another version of Charry's psychological vision of salvation, in that it alleviates the pain of fearful unrest with hope. Within the psychological vision of salvation, salvation is God's mercy and the bodily resurrection, in response to the fear of divine wrath and the fear of death.

Secondly, salvation is described as transformation, as the restoration of personal integrity and strength (2004c:293). In this view, salvation is not the opposite of fear or anxiety, but of illness and disorientation. This disorientation, writes Charry (2004c:293), is the lack of skills and resources 'needed for our transformation, and the clarity of mind even to discern what ought to be done.' This second vision makes use of an 'illness-to-health model of salvation' in which God makes a 'therapeutic alliance' with human beings in order for human beings to 'get better [and] genuinely stronger by having the power of God working in us and for us' (2004c:294). Upon this understanding, the dynamic of salvation is transformation by, through and into love: 'We become what we love' (2004c:294). Within the transformational vision of salvation, salvation is healing 'ensouled bodies', the strengthening or growth into the beauty and wisdom of God, and the pleasure or joy of being transformed through, by and into love. Yet (Charry 2004c):

As with all articulations of Christian tradition, particular visions of salvation wax, wane, and are transformed as new circumstances call forth different perspectives, giving rise to new insights about how Christian hope may best be conveyed to one another in a particular time and place. How theology articulates salvation today will depend in part upon how one reads the culture and what restatements of the vision actually succeed in giving hope. For the vision of salvation offered must strike home. It must give us what we need. It must cure our souls. (p. 294)

For Charry's interpretation of salvation, healing and hope is intimately connected. Moreover, she suggests that visions of salvation be judged by their ability to 'bring hope $^{\prime 17}$ and 'cure souls' (2004c:294). This twofold criterion for visions of salvation - bringing hope and curing souls plays a particularly important role in the development of soteriology in Charry's later work, such as her God and the art of happiness (2010).

Moreover, Christian soteriology needs to take embodied human existence seriously, argues Charry, because (1) human beings are not only their bodies, or their minds, or their spirits, but whole persons (2004c:295); and because (2) 'God cares about us in our full integrity: heart, soul, mind, and strength' (2004c:296). This seems to imply for her, that salvation engages the full range of human senses in experiencing God. In salvation, human beings 'taste God' and receive a 'foretaste of heaven' (Charry 2004c:296), and God's power and love is visible, tangible, edible, audible and fragrant (Charry 2005b:208). Again, hope and healing are inseparably linked in such a vision of salvation.

Christian faith does not merely celebrate human life, argues Charry (1993:101), but 'seeks to transform human persons through the grace of God in Jesus Christ by the Holy Spirit.' Salvation as transformation, expressed in healing, beauty and pleasure, means 'maturing' or 'growing into the wisdom of divine love and enjoying oneself in the process' (2010:x). For Charry, salvation is centered in sanctification (2010:x), though not as a 'private possession' or as a 'personal prize'. Salvation, for Charry, is 'a way of life in community' (2005b:212) in that believers are engrafted into 'the drama of salvation' (2005b:215). Indeed, Christianity is more than either a set of beliefs or a set of practices, in that Christianity is embedded in community, in a shared way of life (2003a:264). ${ }^{18}$

\section{Happy human beings?}

In her book God and the art of happiness (2010) Ellen Charry reviews the historical trajectory of the theological conversation about happiness and offers a proposal as to reopening the theological conversation (2010:ix). She seeks to address the gap between eschatological happiness and temporal happiness in particular. The question for her then is, whether there are sufficient theological resources available to think and talk about happiness within this life. Her practical concern for people who experience suffering and grief and her observation that 'Western Christian theology is skittish about temporal happiness' (2010:ix) shapes her study on the nature and art of happiness. Two episodes frame her narrative of happiness: (1) happiness has primarily been understood in terms of (future) eschatology,

17.This is a particularly interesting point, since it moves between eschatology and soteriology, and may potentially even collapse one doctrine into the other. Yet the instilment of hope appears to be a distinguishing element for Charry in the analyses of different visions of salvation. She writes (2004c:296) that '[a]ll seek analyses of different visions of salvation. She writes (2004c:296) that "a a] seek greatest good, perfect happiness, or holiness.'

18.Therefore the need for 'spiritual friends', those present and those who have gone before, who accompany us in the lives we live (2003a:264). For Charry, these spiritual companions seem to include the classic theologians (particularly these spiritual companions seem to include the classic theologians (particularly
Augustine) whom she consistently refers to in formulating and shaping a Christian doctrine of happiness. 
in that happiness has been to the life hereafter,; ${ }^{19}$ and (2) Protestant theologies focus on the intellectual coherence of their doctrines (instead of the formative power or pastoral function thereof) has problematised the very possibility of a theological conversation on happiness (2010:x).

Yet Charry argues that the time has come for the theological conversation on happiness to be reopened, 'for the sake of God's great Yes' (2010:x). In this regard she takes her cue from Karl Barth (2010:x, 1997:28-29) and in particular from what she regards as Barth's correction on John Calvin. She writes (1997:29) that 'Calvin's lugubriousness ... supports a punitive and guilt-ridden identity that Barth considers incompatible with God's grace', ${ }^{20}$ and that even though Barth 'is not motivated by the modern psychological insight that a guilt-ridden personality is unhealthy', Barth understood the pastoral power of doctrines (such as the doctrine of sin) (1997:29). For her, Karl Barth is one example of a recent theologian who is concerned with the salutarity in Christian theology and of Christian doctrine in particular (1997:28).

Ellen Charry argues for a salutary understanding of happiness, whereby she seeks to reconnect goodness to happiness. She observes that the Christian witness to happiness within scripture and tradition may find appropriate conversation partners in modern psychology and philosophy with regards to understanding excellence and flourishing, but that both Christian and non-Christian notions of happiness and flourishing need to be judged by the 'salutarity principle' (1997:30). For her, '[l]iving well is key to a happy life' (2004b:20) in that goodness and happiness are inseparable (Charry 2006b:163). She observes that this has not always been the case within theology, in that 'Christian doctrine has not adequately linked piety to pleasure' (Charry 2010:xii) - which has lead to the creation of a 'theological gap' between happiness and goodness. The unlinking of goodness to happiness has lead to the linking of excitement to happiness instead. Christian doctrine has ceded the term 'happiness' to the marketplace, and so it has again become the task of theology to (re)define and (re)intrepret happiness theologically (Charry 2010:xii).

She traces three errors made by modernity and one error made by Christian theology in thinking about happiness.

\section{She relates this to theologians' embarrassment at Friedrich Nietzsche's criticism of the Christian faith's pessimistic view of the human condition. She writes that theologians consequently relocated 'value and goodness away from earthly and human things' and taught the despisal of human pleasures, such as marriage and politics (1993:100). Nietzsche argued that 'the Christian judgment is psychologically destructive for everyone, for it undercuts the drive for power, self- preservation, and control over one's life while it exalts suffering, helplessness, and even promotes poor hygiene!' (Charry 1993:100) However, Charry admits that 'Christianity has not always been conducive to the psychological well-being of all persons' and that the challenge to Christian faith lies in how it promotes human dignity and uphold human personhood (1993:100).}

20.For Eric Johnson, this evaluation of Calvin's theological stance on happiness strikes a 'discordant note', in that Charry's portrayal of Calvin (and Luther, he adds) appears to be 'hasty' and 'unsympathetic' - that is, 'in contrast to the more detailed and favourable discussions of other Christians, even Boethius' (2011:257). As such, Johnson reads Charry as depicting Calvin as 'an enemy of Christian happiness' and as 'guilt- and anxiety-ridden promoters of self-deprecation' (2011:257). Johnson argues that this would 'surprise those who have actually found some divine argues that this would surprise those who have actually found some divine
happiness reading Luther and Calvin and [who have applied] their gospel remedies happiness reading Luther and Cal
to their own guilt' (2011:257).
The first error is thinking that happiness is just about ourselves, about the individual's private, personal life and preferences. Indeed, 'modernity lost appreciation for the sociality of happiness' (Charry 2004b:23). The second error is to confuse 'a constant state of euphoria' with happiness. Charry would rather assert happiness as 'a power of the soul' (2004b:23). The third error is to assume that 'we know what will make us happy and that we are able to get it' (2004b:23). These three errors constitute what Charry describes as 'the quest for self-gratification' which has, in modern times, come to substitute salvation (2004b:23). Modern philosophy may have trivialised happiness by converting it into a private feeling, but the Christian faith has contributed a fourth error by being completely absent in the discussion on happiness. A suspicion of pleasure and the enjoyment of life have contributed to the abovementioned trivialisation of happiness (Charry 2004b:23-24). Ellen Charry warns of a notion of happiness that is devoid either of goodness (so that happiness becomes 'mere fun') or material satisfaction (so that happiness becomes disconnected from life in this world) (Charry 2004b:25).

In her critique of 'the modern self', Charry writes that ' $[t]$ he secular self is grounded in itself' (1998:95) and so is based on the assumption that 'the self [contains] within itself all that it [needs] to provide its own happiness' (1998:98). It is preoccupied with itself: with 'self-sufficiency' (1998:96), 'self-mastery' (1998:97), 'self-trust' (1998:99), 'self-direction' (1998:100), 'self-construction' (1998:100), 'self-creation' (1998:100), 'self-respect' (1998:100), 'self-formation' (1998:100), 'self-expression' (1998:100), 'self-esteem' (1998:101), 'selfrestraint' (1998:104), 'self-sacrifice' (1998:104), 'self-fulfillment' (1998:104), 'self-gratification' (1998:105), 'self-image' (1998:102), 'self-actualization' (1998:102), 'self-realization' (1998:102), 'self-control' (1998:102), and 'self-construction' (1998:107). The underlying assumption here is that the 'romantic-expressive modern self' (1998:104) 'must be unconstrained in order to flourish' (1998:102-103). Flourishing and happiness is confined to the self, and without the broader context for happiness and flourishing that God provides the modern self is rendered 'anomic', 'amoral', 'asocial' and 'alone' (1998:103-104). ${ }^{21}$

Yet this is not the story that Ellen Charry imagines for theology's engagement with happiness. 'Happiness', writes Charry (2010:x), 'is a realizing eschatology with salvation centered in sanctification.' The source and meaning of happiness lies not in human beings themselves, but in God. For her, intimacy with God or 'dwelling in the being of God' (1998:104) grounds the Christian self. ${ }^{22}$ At this point

21.Yet in a later article Charry (2011:291) would argue that there is and ought to be a theological engagement and affirmation of 'genuine self-confidence, self-love, and self-appreciation amidst the struggle of the divided self.'

22. Here Ellen Charry (1998:106) calls upon the Christian tradition to support her point: 'The teaching of intimacy as the way to a proper self, found in Paul and Augustine and elaborated in the Orthodox tradition, through its doctrine of theosis, is not permission to withdraw from the world. The modern self, as we have seen, depends - or at least claims to depend - on itself alone. That is the source of its fragility and instability. It is chaned to what it can know and do on its own. 
Christian psychology ${ }^{23}$ becomes of great importance to Charry's argument. She argues that it provides us with 'a theological context for the formation of the self' in that '[o]ur identity is not self-constructed but given by God and rooted in the being of God' (1998:107). The goal of Christian (moral) psychology is the correction of doctrinal formulations that are abusive and oppressive and the affirmation of the goodness of bodily, natural, material living (1998:111). Stated somewhat differently, Christian psychology as Charry interprets it argues for a balance between a 'defect-based psychology' (2011:285) or 'pathology-driven narrative' (2011:284) and a 'strength-based psychology' (2011:285). ${ }^{24}$ Classic Western Christian Psychology (CWCP) focuses on the ontological realities of creation and fallenness of human nature (2011:286) and the psychological concern of balancing divine wrath with divine compassion (2011:288).

A major point of overlap between Christian theology and positive psychology lies in the use of the term 'flourishing. ${ }^{25}$ Ellen Charry uses the term 'flourishing' in relation to salvation and happiness in her work, but does not provide a clear definition of the term in any of her books or articles. ${ }^{26}$ Yet she traces some of the implications of what she means by 'flourishing' in her argument that theology is concerned with human happiness: that psychological and moral flourishing are related to goodness, beauty and wisdom (2002:175); that flourishing is deeply embedded in communitarian and social responsibilities (2002:176); ${ }^{27}$ that human beings flourish when they know, love and enjoy God (2002:176); that we flourish 'only when transformed by being taken up into the

23.Ellen Charry defines Christian psychology and articulates the role of theology within Christian psychology as follows (2011:284): 'Christian Psychology embraces those disciplines that speak of the soul ... from within Christianity, encouraging a transdisciplinary dialogue. Theology is central to that discussion because it sets the terms for thinking about nature in broad sweep ... [t] hat is, Christianity carries a set of psychological commitments that ground all attempts to think about the soul, or the self as moderns have translated psyche.'

24. Here Charry engages with Martin Seligman and other positive psychologists who hope to supplement the focus on defects and illness in psychology with strengths and abilities (2011:285). Positive psychology is primarily interested in 'health', 'resilience', 'hardiness' and 'strength' (cf. Charry 2011:288), a in 'health', 'resilience', 'hardiness' and 'strength' (cf. Charry 2011:288), a (2011:288-292). She illustrates how this can be done in her article 'Positive Theology' (2011), wherein she explores the role that the sacraments and pneumatology can play in formulating a theological discouse of encouragement (2011:290-291)

25.'Flourishing' is a popular term within positive psychology, so much so that Martin Seligman's latest book is entitled Flourish (2011). Indeed, '[ $h]$ appiness and human flourishing have both been explored by positive psychologists over the past 15 years' (Johnson 2011:256).

26.Yet, as Dustin Resch also remarks, ' $[t]$ he reader of Charry's book is left, not with a concise description of happiness as a philosophical and theological formula but with strands of biblical and theo a pal tradition that evoke further formula, but with strands of biblical and theological tradition that evoke furthe rumination with the own hope for happiness (2013:485). The point of this article is also not to "provide the reader of Charry with either an exact definition of 'flourishing' or 'happiness', or with a complete set of exhaustive definitions of all terms relating to her use of 'flourishing' or 'happiness'. Rather, the aim here is to portray her argument, made over many years in various kinds of publications, regarding the doctrine of salvation and how human happiness is to be understood from her broader understanding of how Christian doctrines are to function. Moreover, the semantic field within which her use of 'flourishing' and 'happiness' is embedded - by use of such terms as 'healing', 'beauty' and 'pleasure' - is sketched, without necessarily providing precise definitions of each of these terms or an exact delimitation of this semantic field, seeing as this is not to be found in her own written work.

27.The vision of flourishing stands in service of God and neighbour, argues Charry (2002:176), and is therefore in the interests of the common good, in that it forms 'the foundation of a healthy and prosperous social fabric for civilization' (2002:176). Yet some, like Paul Wadell and Colin Gunton, would ask whether there is enough of 'an ecclesiological dimension' (Gunton 1998:456) or an adequate account 'of the an ecclesiological dimension' (Gunton 1998:456) or an adequate account 'of the
kind of community "asherism" calls the church to be' (Wadell 2012:363) in Charry's kind of community "asherism" calls the church to be' (Wadell 2012:
working from a theology of happiness or doctrine of salvation. divine life' (1998:98). At points it may seem as if she uses the terms 'flourishing' and 'happiness' interchangeably (cf. 2004b:26). However, what is clear is that, for Ellen Charry, God wills the flourishing, 'the abundant life', of human beings (1998:111).

An important characteristic of Charry's use of 'happiness' is the proximity of a creative logic of love. At the heart of Charry's theological work on happiness is 'the ability to love well' (2007:33). A healthy personality that is formed by the love of God is an agile self, a 'functionally loving character' (2007:33). She writes that '[ $h$ ]appiness comes as we find ourselves and those around us flourishing because we have enhanced their well-being' and that ' $[t]$ his is a proper form of Christian love' (2007:32). In her article 'Academic theology in pastoral perspective' (1993), the task of wisdom is 'happiness' and the method or means to this is 'love' (1993:93). Love is fundamental to Charry's understanding of happiness (1993:94). 'Love', writes Charry (2006b):

$[I]$ s not simply an emotion but is the presence of the beloved in the lover. Love leaves the fragrance of itself in the soul, just as sitting beside a glowing fire leaves its aroma on one's clothes, or embracing someone wearing perfume leaves a trace on one's body. (p. 166)

This logic of love permeates Charry's understanding of happiness, and guides and shapes how salvation is expressed in her work and thinking. In healing, beauty and pleasure God's creative love for all humankind is expressed. This is what Charry means when she writes that 'God is key to happiness in this life' (2004b:20), in that the depth and scope of a theological conversation on happiness is lost when God's will for the flourishing of human beings is not affirmed. Happiness has to do with the love of God as expressed in the salvation of human beings, and is therefore grace, a gift freely given. However, being or becoming happy is also a skill, a spiritual art learned through the guiding and shaping forces (or moral formation) of Christian doctrine (cf. Charry 2004b:28). Therefore it needs to be added that knowing, loving, enjoying God is the means to happiness. Human beings 'flourish by knowing and loving God' (1997:3). Yet, argues Charry (1997:3), 'God is not only good to us but good for us', and therefore flourishing that finds its origin in the enjoyment of God has consequences and implications for our relationships with one another (1997:3).

Knowing, loving and enjoying God are skills that are developed and honed over time - in short, the art of happiness (cf. Charry 2010). 'The maturing self' ${ }^{28}$ is skillfully, artfully guided and shaped by God (2006b), through love:

As it happens with human lovers, it happens between God and us. By staying together over a long period, attending to their lover's manners, needs, and gifts, and being vulnerable to the other's very presence, human lovers become one flesh. (p. 169)

28.Emotional and intellectual security, argues Charry (2005a:162-163), require 'a reflective bent of mind, emotional depth, and a philosophical or theological orientation to ground and guide one's judgments.' 


\section{Conclusion}

Theology, for Ellen Charry, has a distinctive calling 'to incite persons to a good and happy life by knowing, loving and enjoying God' (2006b:150). Indeed, happiness is deeply rooted in the Christian tradition, argues Charry (2007:31). ${ }^{29}$ It follows that the theological task, for Charry, entails deriving 'knowledge of God that makes for a good and happy life for others' (2006b:163). Christian doctrine, wherein knowledge of God comes to expression in the church, guides and shapes human beings into people who live their lives excellently (2010:x), with dignity, nobility of purpose and happiness (1997:3; 2004b:28). Therein lies a theologically sound foundation for happiness as 'a life nourished by love and goodness of God that contributes to the flourishing of creation' (2007:33). Perhaps, then, it could after all be argued that Charry's 'retrieval of and reinvestment in the resources of the Christian tradition' may contribute toward 'developing a richer psychology for the Christian community of the 21st century' (Johnson 2011:257)..$^{30}$

\section{Acknowledgements Competing interests}

The author declares that she has no financial or personal relationship(s) that may have inappropriately influenced her in writing this article.

29.'Happy is the very first word of the Psalter. Matthew uses the word happy to describe those who take on the yoke of Jesus. Augustine uses the word happiness to describe the goal of life' (Charry 2007:31). Yet Charry has been criticised by different theologians and in different publications, regarding her use of the Bible. Colin Gunton, for instance, points to the absence of 'Old Testament themes' in her first book (Gunton 1998:456-457; cf. Charry 1997) - whereas others, like Dustin Resch, emphasise the 'strained nature of her attempt to fit all biblical commands into a pedagogical mode' (particularly with regards to her exegesis of the Pentateuch) in her second book (Resch 2013:485; cf. Charry 2010).

30.Indeed, Eric Johnson would go even further and describe Ellen Charry as the theologian [who] has performed an invaluable service to Christians in psychology and counseling by retrieving for us a robustly Christian articulation of happiness' (2011:257). Charry's thinking therefore not only has important interdisciplinary implications, one could argue from Johnson's assessment of Charry's particular portrayal of salvation, but also important intradisciplinary implications - in that (1) portrayal of salvation, but also important intradisciplinary implications - in that (1) it 'has many personality, psychopathology, and psychotherapy implications', and (2) 'it offers a markedly different account of human nature than one finds in the pages of modern psychology' which 'have not been much explored by Christians in the field' (2011:256).

\section{References}

Charry, E.T., 1992, 'The moral function of doctrine', Theology Today 49(1), 31-45. http://dx.doi.org/10.1177/004057369204900104

Charry, E.T., 1993, 'Academic theology in pastoral perspective', Theology Today 50(1), 90-104. http://dx.doi.org/10.1177/004057369305000111

Charry, E.T., 1997, By the renewing of your minds. The pastoral function of Christian doctrine, Oxford University Press, New York.

Charry, E.T. 1998, 'The crisis of modernity and the Christian self', in M. Volf (ed.), A passion for God's reign. Theology, Christian learning and the Christian self, pp. 89-112, William B. Eerdmans Publishing Company, Grand Rapids, MI.

Charry, E.T., 2002, 'To know, love and enjoy God', Theology Today 59(2), 173-178. http://dx.doi.org/10.1177/004057360205900201

Charry, E.T., 2003a, 'How should we live? The Christian Life', in W.C. Placher (ed.), Essentials of Christian Theology, pp. 264-280, Westminster John Knox Press, Louisville, KY.

Charry, E.T., 2003b, 'Welcoming Medieval Christian Women Theologians', Theology Today 60, 1-4. http://dx.doi.org/10.1177/004057360306000101

Charry, E.T., 2004a, 'Christian witness to contemporary culture regarding sex', Anglican Theological Review 86(2), 273-292.

Charry, E.T., 2004b, 'On happiness', Anglican Theological Review 86(1), 19-33.

Charry, E.T. 2004c, 'While visions of salvation dance in our heads', Theology Today 61, 291-296. http://dx.doi.org/10.1177/004057360406100301

Charry, E.T., 2005a, 'Following an unfollowable God', in B. Gaventa \& P.D. Miller (eds.), The Ending of Mark and the Ends of God. Essays in Memory of Donal Harrisville Juel, pp. 155-163, Westminster John Knox Press, Louisville, KY.

Charry, E.T., 2005b, 'Sacramental ecclesiology', in M. Husbands \& D.J. Treier (eds.) The community of the Word. Toward an Evangelical ecclesiology, pp. 201-216, Intervarsity Press, Downers Grove, II.

Charry, E.T., 2006a, 'Review of five books on happiness "Happy pursuits", The Christian Century 124(15), 33-36.

Charry, E.T., 2006b, 'Walking in the truth: On knowing God', in A.G. Padgett \& P.R Keifert (eds.), But is it all true? The Bible and the question of truth, pp. 144-169, William B. Eerdmans Publishing Company, Grand Rapids, MI.

Charry, E.T., 2007, 'Happy pursuits: A Christian vision of the good life', The Christian Century 24 July, 31-33.

Charry, E.T., 2010, God and the art of happiness, William B. Eerdmans Publishing Company, Grand Rapids, MI.

Charry, E.T., 2011, 'Positive theology: An exploration in theological psychology and positive psychology', Journal of Psychology and Christianity 30(4), 284-293.

Gunton, C.E., 1998, 'Review of By the renewing of your minds, by E.T. Charry', Theology Today 55(3), 454-458. http://dx.doi.org/10.1177/004057369805500317

Johnson, E.L., 2011, 'Review of God and the art of happiness, by E.T. Charry', Journal of Psychology and Christianity 30(3), 255-257.

Marais, N., 2013, 'Personal communication', 03 April, Princeton, NJ.

Resch, D., 2013, Review of God and the art of happiness, by E.T. Charry, Internationa Journal of Systematic Theology 15(4) 483-485. http://dx.doi.org/10.1111/j.14682400.2011.00586.x

Seligman, M., 2011, Flourish. A new understanding of happiness and well-being - and how to achieve them, Random House, Sydney.

Van Dyk, L., 1999, 'Review of By the renewing of your minds, by E.T. Charry', Interpretation 53(1), 103-104. http://dx.doi.org/10.1177/002096439905300138

Wadell, P.J., 2012, 'Review of God and the art of happiness, by E.T. Charry', Modern Theology 28(2), 361-363. http://dx.doi.org/10.1111/j.1468-0025.2012.01755.x 